\title{
Transformation within transportation planning in South Africa: implications for the implementation of the National Transport Master Plan (NATMAP) of 2011
}

\author{
C. B. Schoeman \\ School for Environmental Sciences and Development, \\ North West University (Potchefstroom Campus), South Africa
}

\begin{abstract}
Transport planning in South Africa became a statutory planning activity with the enactment of the Urban Transportation Act (Act 78 of 1977). Transport planning, development and management were guided by the National Land Transport Transition Act (Act 22 of 2000) up to 2009 when the National Land Transport Act (NLTA) (Act 5 of 2009) and its Regulations (2009) were promulgated. In this context various policy documents underpinned this transformation process.

The nexus of the abovementioned policy and legislative framework and the recently approved NATMAP (2011) culminates in a paradigm shift in the formulation of provincial and local transport strategies and its implementation. This paper endeavors to unpack this relationship and to link the transportation transformation process to projects of national significance.

The paper is based on a specific methodology and the main results will be reported on. Recommendations to support the implementation of NATMAP 2050 and to make provision for amendments in the National Spatial Development Perspective (NSDP) (2006) are included. The research has indicated that Integrated Transport Plans (ITPs) for metropolitan areas and intermediate towns needs to be aligned to the NLTA and the perspective of NATMAP 2011.

Keywords: transportation planning, transportation strategies, transportation policy and legislation.
\end{abstract}




\section{Introduction}

Transport and spatial planning in South Africa prior to 1994 focused on the policy of separate development and service provision based on racial spatial segregation. Whilst there is a perception that the Government of South Africa, in 1994 inherited the best transportation system in Africa, the realities indicate extreme disparities between the former advantaged citizen enclaves (urban) and areas predominantly occupied by historically disadvantaged citizens (rural) [1].

Transport planning in South Africa became a statutory planning activity with the enactment of the Urban Transportation Act (Act 78 of 1977) [2]. Transport planning, development and management were guided by the National Land Transport Transition Act (Act 22 of 2000) [3] up to 2009 when the National Land Transport Act (Act 5 of 2009) [4] and its Regulations (2009) [5] were promulgated. In this context various policy documents underpinned this transformation process: White Paper on National Transport Policy (1996) [6]; Moving South Africa (Vision 2020) (1999) [7]; Rural Transport Strategy for South Africa (2003) [8]; and the National Transport Master Plan 2050 (NATMAP 2050) (2006-2011) [9].

The new democracy in South Africa is in its $18^{\text {th }}$ year of existence. Within the context of a transformed policy and legislative framework the challenge remains to socially, economically and spatially grow, develop and normalize all components of the national, provincial and local spatial systems. This challenge is inter alia addressed in the National Planning Commission (NPC) Diagnostic Report (2011) [10]. This position is also addressed in the NPC National Development Plan for 2030 [11]. In addressing this overarching development challenge there are three core instruments that sets the scene for sustainable development in South Africa: National Spatial Development Perspective (2006) [12]; Human Settlement Atlas (2009) [13] and NATMAP [9].

\section{Purpose of the research and methodology applied}

The purpose of this paper is to assess the transformation of transportation planning in South Africa with special reference to the existing policy and legislative framework and its support base to enhance the implementation of the strategies as contained in NATMAP (2050) [9].

The research methodology will include the following focuses:

- Problem statement.

- Policy and legislative framework.

- Overview of NATMAP 2050.

- Transportation planning and delivery performance since 1994.

- Alignment and integration considerations.

- Conclusions. 


\section{Problem statement}

Based on the reality as summarized under point 1 and point 2 above problems and challenges related to the management of the interface between transportation planning, spatial planning and environmental management processes (policies and legislative frameworks) in South Africa is a well known area of debate.

Practitioners working in transportation and spatial planning within the public and private sectors have interpreted the interface for different reasons in various ways. The evolution over the past decade of policy and legislative frameworks (as indicated above) directing these processes did not necessarily promote a common or improved understanding of the interface between the supporting processes and professions involved. Notwithstanding the transformation process most professions within the private and public sector still function in isolation.

The fact that the policies referred to above represents various focuses results in a deepening of the divide between professions and spheres of government. Due to the focus of the core instruments as identified above, this paper endeavours to address this lack of integration even if it only relates to the identification of common challenges to overcome social, economical and spatial fragmentation within spatial systems within South Africa.

\section{Policy and legislative frameworks}

\subsection{National perspective}

The transformation of transport planning (land transport) and spatial planning and development in South Africa within the national sphere of government is being guided through the policy and legislative framework timeline as shown in Table 1.

In essence the transformation of transportation planning developed as follows:

The National Department of Transport, in June 2000, initiated a process to formulate the National Land Transport Transition Act (Act 22 of 2000) [3]. The first step in the process was to review the then planning approaches and processes as it was applied in the period 2000 to 2006. A further draft document containing specific guidelines and requirements for the preparation of Integrated Transport Plans (ITPs) were produced by the Department of Transport in 2007 [14]. The abovementioned documents did not replace any of the existing Committee of Land Transport Officials (COLTO) guidelines for integrated transport planning prepared during the period 1997 to 1998. These guidelines consist of the TPG-series as documented by COLTO (now known as COTO).

Since 1994 with democratization, the two policy documents that are of significance included the White Paper on National Transport Policy (1996) [6] and the Moving South Africa (Vision 2020) (MSA) (1999) [7] as published by the Department of Transport. These documents endeavored to address some of the transport and spatial implications and deficiencies inherited by the democratic government. The MSA included a vision for transport in 2020; 
foundations for a transport strategy; urban and rural passenger transport; tourists and long distance customers; special needs customers; freight transport; recommendations on integrating the strategic framework and a way forward. For the first time in the history of South Africa, the government has developed a framework which integrated all parts of transport into a common vision and plan for action.

Table 1: Transformation of core policies and legislative framework for transport planning and spatial development.

\begin{tabular}{|c|c|}
\hline Policy framework & Legislative framework \\
\hline $\begin{array}{l}\text { White Paper on National Transport Policy } \\
\text { (1996) }\end{array}$ & Urban Transport Act (Act 78 of 1977) \\
\hline Moving South Africa (Vision 2020) (1999) & Road Transport Act (Act 74 of 1977) \\
\hline $\begin{array}{l}\text { White Paper on Spatial Planning and Land Use } \\
\text { Management (2001) }\end{array}$ & Development Facilitation Act (Act 67 of 1995) \\
\hline $\begin{array}{l}\text { National Spatial Development Perspective } \\
(2003)\end{array}$ & National Road Traffic Act (Act 93 of 1996) \\
\hline $\begin{array}{l}\text { Rural Transport Strategy for South Africa } \\
(2003)\end{array}$ & $\begin{array}{l}\text { Constitution of the Republic of South Africa } \\
\text { (Act } 108 \text { of 1996) }\end{array}$ \\
\hline $\begin{array}{l}\text { National Spatial Development Perspective } \\
\text { (2006) }\end{array}$ & $\begin{array}{l}\text { National Transport Interim Arrangements Act } \\
\text { (Act } 45 \text { of 1998) }\end{array}$ \\
\hline $\begin{array}{l}\text { Accelerated and Shared Growth-South Africa } \\
\text { (ASGISA) (2006) }\end{array}$ & $\begin{array}{l}\text { Cross Border Road Transport Act (Act } 4 \text { of } \\
\text { 1998) }\end{array}$ \\
\hline $\begin{array}{l}\text { Draft minimum requirements for the preparation } \\
\text { of integrated transport plans (ITP) (2007) }\end{array}$ & Transport Appeal Tribunal Act (At 39 of 1998) \\
\hline $\begin{array}{l}\text { National Land Transport Strategic Framework } \\
\text { (2006-2011) (2002) (Draft) }\end{array}$ & Road Traffic Act (Act 29 of 1989) \\
\hline $\begin{array}{l}\text { Rural Transport Strategy for South Africa } \\
\text { (2003). }\end{array}$ & Municipal Stru \\
\hline $\begin{array}{l}\text { Sustainable Human Settlement Planning (2009); } \\
\text { Human Settlement Atlas (2009) }\end{array}$ & $\begin{array}{l}\text { National Land Transport Transition Act (Act } 22 \\
\text { of 2000) }\end{array}$ \\
\hline National Housing Code, 2009. & Municipal Systems Act, (Act 32 of 2000) \\
\hline National Growth Plan (2009) & National Land Transport Act (Act 5 of 2009) \\
\hline $\begin{array}{l}\text { National Transport Master Plan } 2050 \\
\text { (NATMAP 2050) (2011) }\end{array}$ & $\begin{array}{l}\text { R. } 1208 \text { National Land Transport Act (5/2009): } \\
\text { National Land Transport Regulations. }\end{array}$ \\
\hline $\begin{array}{l}\text { National Planning Commission (NPC) } \\
\text { Diagnostic Report (2011) }\end{array}$ & $\begin{array}{l}\text { R. } 877 \text { National Land Transport Act (5/2009): } \\
\text { National Land Transport Regulations on } \\
\text { Contracting for Public Transport Services. }\end{array}$ \\
\hline $\begin{array}{l}\text { National Planning Commission (NPC): National } \\
\text { Development Plan for } 2030 \text { (2011) }\end{array}$ & $\begin{array}{l}\text { Spatial Planning and Land Use Management Bill } \\
\text { (2012) }\end{array}$ \\
\hline
\end{tabular}

Source: Own construction, 2012

The White Paper on National Transport Policy (1996) [6] included a number of strategic objectives for land passenger transport. These strategic objectives consisted of certain targets to improve the transport system. The targets were based on an analysis of critical issues and problems facing land transport in South Africa at the time. Amongst the issues identified were the supply-driven nature of public transport system, neglect of customers and the inefficient implementation of public transport subsidization [15].

The outcome of the White Paper and MSA has been incorporated into legislation [3] intended to implement the transport policies and strategies. The 
NLTTA (2000) includes provisions for monitoring the performance of the public transport system and measuring performance in respect of key performance indicators (KPIs). In 2002 the National Land Transport Strategic Framework (2006-2011) [16] was completed in draft format that provided for a strategic framework for transportation focus and development.

The most progressive transformation element within transportation planning in South Africa occurred in 2009 with the promulgation of the National Land Transport Act (5 of 2009) and its supporting regulations [5]. Of significance in this transformation process is the fact that the NATMAP (2050) [9] planning process commenced in 2006. These two core instruments will form the departure point for transportation planning reform in the next decade. It will serve as the catalyst in transportation development in South Africa.

\subsection{Provincial perspective}

For the purposes of this paper, it should be noted that within the provincial sphere of government further provincial policies and legislative frameworks applies. The context thereof normally consists of legislation guiding land transport planning; provincial growth and development strategies (PGDS); provincial spatial development frameworks (PSDF); provincial land transport frameworks (LTPF) and environmental policies and strategies.

\subsection{Municipal perspective}

Similar instruments guiding transport and spatial planning and development exist within the third sphere of government (municipal) including integrated development plans (IDP); spatial development frameworks (SDF); integrated transport plans (ITP); environmental management frameworks (EMF) and strategic environmental assessments.

Figure 1 shows the framework within which transport planning, service provision and delivery takes place within municipalities. As can be deduced the core policies and legislation of all spheres of government influence and impacts on transport planning and delivery. Grey and Ncunyana [17] gave an overview of the role of municipalities in transport service delivery. They [17] emphasize that the integrated transport plan (ITP) mission is to enhance the effective functioning of cities, towns and rural areas through integrated planning and provisioning of transport infrastructure and services. The integrated development plan (IDP) embraces the ITP as a tool for transport service delivery at district and local municipality level.

From Figure 1 it is clear that transport planning interfaces with environmental management, spatial and statutory planning. At the same time communication and participation in line with the applicable policy and legislative framework fulfills a fundamental role in delivery.

Stapelberg [18] discussed the role of transport planning in the quest for sustainable land use. He concluded that the aim is to have cities, communities, planning and development that can be sustainable and in the process to have effective transport systems. 


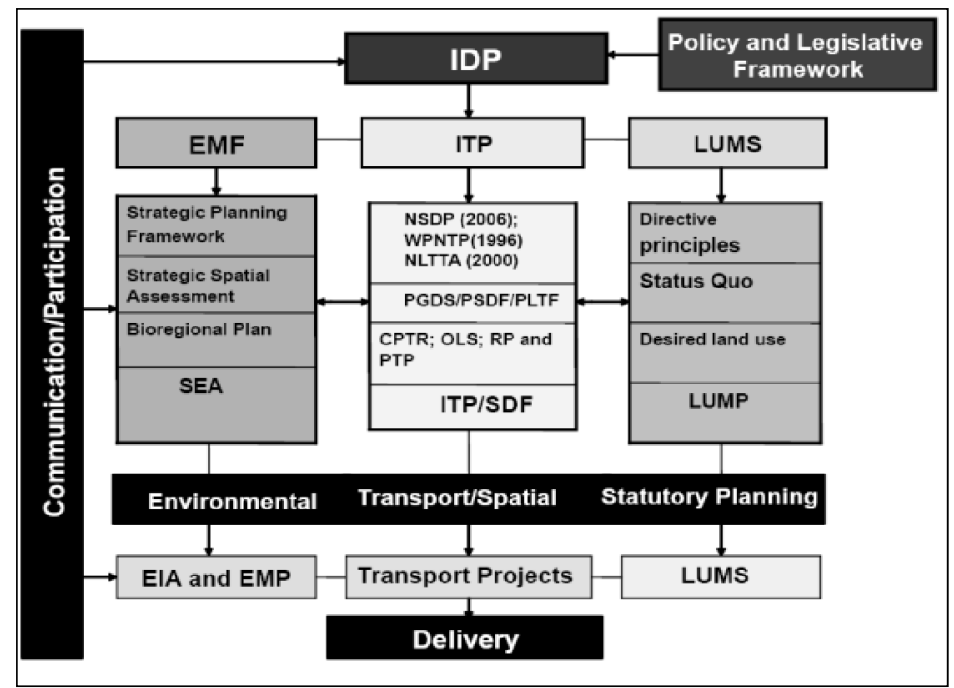

Figure 1: Integrative framework for transport planning and development within municipalities.

\section{Overview of NATMAP (2050)}

\subsection{Background}

NATMAP (2050) indicates that transport is a prerequisite, although not a guarantee of the socio-economic development of the Republic of South Africa as a whole. In the development of National Transport Master Plan 2005-2050 (NATMAP 2050), it was necessary to identify and crystallize existing perennial problems and those which resulted from alternative socio-economic development strategies and indicated how best these may be tackled [19].

\subsection{Goals and objectives}

The NATMAP (2050) goal is to develop a dynamic; long term; and sustainable land use/multi-modal transportation systems framework for the development of networks infrastructure facilities; interchange termini facilities and service delivery that shall be demand responsive to national/provincial/district and/or any socio-economic growth strategy, and/or any sectoral integrated spatial development plan [19]. The following project objectives were formulated:

- Maximize utilization of existing infrastructure facilities;

- Development of future infrastructure facilities and improve operations;

- Development of an up to date and accurate central land use/transportation DATA BANK - Geographic information systems (GIS);

- $\quad$ Promote effectiveness and efficiency of maritime transport; 
- Integrated multimodal public passenger transportation;

- Determine the economic role of transport; and

- Integration of transport and land use development.

\subsection{Phases of the NATMAP (2050) planning process}

The NATMAP 2050 project is structured in four phases (refer to Figure 2):

- The Status quo, Phase 1, provides an overview of current transportation systems, land use, demographic and socio economic conditions.

- The Analysis, Phase 2, dissects the status quo information and accordingly this phase represents the quantitative analysis of different land use/transportation integrated scenarios.

- Forward Planning, Phase 3, is not "what is, or what will be, but simply what ought to be”. Given a clear understanding of the current situation and the impacts on society as derived from the previous two phases, this phase is about the alternative strategies that can be followed in the future and consequently also the decisions to be made.

- The Agenda for Action, Phase 4, takes the alternative strategies to its final stage, focusing on an action agenda for implementation [19].

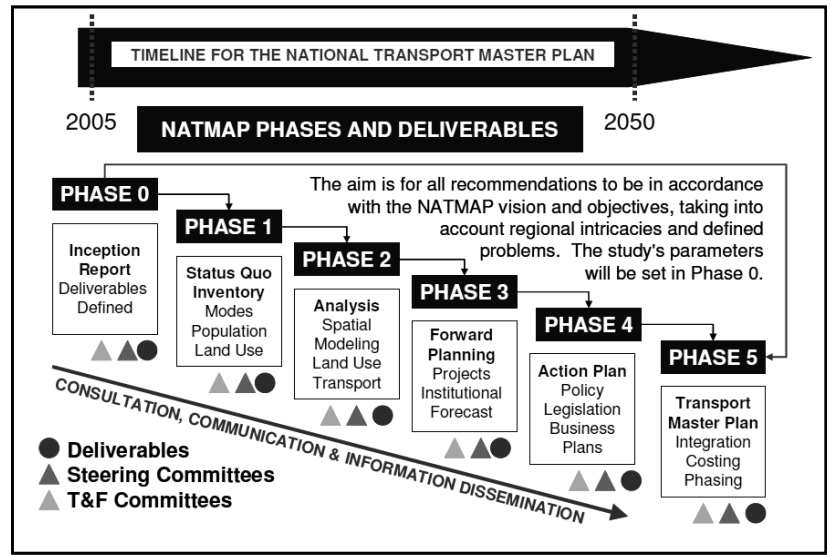

Figure 2: $\quad$ NATMAP (2050) project phases.

The scope of a National Transport Master Plan [9, 19] is to examine, determine, and crystallize the relationship between various land uses and the consequential transportation requirements/needs. In addition, Department of Transport has initiated this project to achieve a coordinated, efficient and cost effective transport plan investment strategy and to streamline transport planning vertically (among the transport/planning authorities) and horizontally (across all modes). 


\section{Transportation planning and delivery performance since 1994}

\subsection{Quantitative and qualitative methods of performance assessment}

Transport performance can be measured in terms of quantitative or qualitative assessment methods. Krynauw and Cameron [15] states that the Draft National Land Transport Strategic Framework (NLSTF) (2002) [16] identified two types of key performance indicators (KPIs):

- Customer-based indicators, which measure the performance of the land transport system from the customer's point of view.

- NLTSF-based indicators which measure the progress of the National and Provincial Departments of Transport and municipalities in implementing the 13 strategies contained in the NLTSF.

The authors [15] discussed the linkage between performance management and decision-making and the notion of transport in support of sustainability. In the process they compare performance indicators for 2002/03 for Johannesburg in terms of the approach as contained in the draft NLTSF (2002) [16] and the Gauteng Provincial Land Transport Framework (2002) [20].

In 2005 Van den Berg et al. [21] used transport performance indicators in order to benchmark the position in Tshwane against other world cities. This methodology is applicable where the research is focused on a specific geographical entity. The viewpoint is based on the conclusion by Van den Berg et al. [21] that the major gaps to be closed before Soccer World Cup 2010 relate largely to operations and management rather than to infrastructure.

The application of such methodologies is however not supportive to analyze transport planning within the national spatial system and thus transformation performance based on the theme of this paper. Performance in this context relates more to development of qualitative; process approaches and focus.

\subsection{Transportation planning projects}

Transportation planning and development in terms of the strategy and objectives as included in the policy and legislative framework (Table 1 above) within the national spatial system took place over the past 18 years within the budgetary system of the Department of Finance. In addition to this strategic and programme based approach, the transport development needs for the World Rugby Cup (1995); Cricket World Cup (2003) and Soccer World Cup (2010) resulted in additional ad hoc investment in transport infrastructure, management and operations to support the events. It also contributed to the development of tourism. The impact; direct and indirect advantages in transportation infrastructure development is a positive inheritance within all of the cities and towns where infrastructure and transportation system development and upgrading were implemented. Investment in transport also focuses to achieve the Millennium Development Goals (MDG) [22]; Accelerated Shared Growth Initiative of South Africa (ASGISA) (2006) [23] and National Growth Plan (2009) [24]. Table 2 gives an overview of the capital spending on transportation 
related infrastructure, management and operations as envisaged in 2008 by NDOT.

From Table 2 it is evident that some $€ 55.23$ billion will be invested in transport and related infrastructure over 5 years (2008 to 2013). This excludes other direct and indirect investment in transport by provinces and municipalities since 1994.

Table 2: $\quad$ Investment capital in transport and related infrastructure (2008).

\begin{tabular}{|c|c|c|}
\hline Investment (R) & Project/programme & Sector and benefit \\
\hline R500 billion ( $€ 40$ billion) & $\begin{array}{l}\text { Integrated public sector } \\
\text { infrastructure investment } \\
\text { programme. Promotion } \\
\text { of existing Government } \\
\text { Programmes } \\
\end{array}$ & $\begin{array}{l}\text { National, provincial and local sphere } \\
\text { of government. Private sector } \\
\text { contractors. Job creation for } \\
\text { community. Tourism enhancement }\end{array}$ \\
\hline R9.6 billion ( $€ 0.77$ billion) & $\begin{array}{l}\text { Construction of } \\
\text { stadiums for } 2010\end{array}$ & $\begin{array}{l}\text { Local municipalities and Private } \\
\text { sector. Job creation and enhancement } \\
\text { of skills development }\end{array}$ \\
\hline R20.0 billion ( $€ 1.6$ billion) & $\begin{array}{l}\text { Airport development } \\
\text { (next } 5 \text { years) }\end{array}$ & $\begin{array}{l}\text { Private sector, job creation, tourism } \\
\text { enhancement }\end{array}$ \\
\hline $\begin{array}{l}\text { R400 million (€32 } \\
\text { million) }\end{array}$ & $\begin{array}{l}\text { Air traffic navigation } \\
\text { systems }\end{array}$ & $\begin{array}{l}\text { Private sector and development of the } \\
\text { aviation industry }\end{array}$ \\
\hline R7.7 billion ( $€ 0.62$ billion) & $\begin{array}{l}\text { Taxi Recapitalization } \\
\text { Programme }\end{array}$ & $\begin{array}{l}\text { Taxi industry, passengers, tourism } \\
\text { sector development, job creation }\end{array}$ \\
\hline R70 billion ( $€ 5.6$ billion) & $\begin{array}{l}\text { Preservation and } \\
\text { upgrading of road } \\
\text { network infrastructure }\end{array}$ & $\begin{array}{l}\text { Private sector, road users, passengers, } \\
\text { community, traffic safety, job creation } \\
\text { and skills development and tourism } \\
\text { enhancement }\end{array}$ \\
\hline R3 billion ( $€ 0.24$ billion) & $\begin{array}{l}\text { Access road } \\
\text { improvement under the } \\
\text { Extended Works } \\
\text { Programme }\end{array}$ & $\begin{array}{l}\text { Private sector, public sector, road } \\
\text { users, traffic safety, job creation and } \\
\text { skills development, urban and rural } \\
\text { integration }\end{array}$ \\
\hline R23 billion ( $€ 1.84$ billion) & $\begin{array}{l}\text { Gauteng Freeway } \\
\text { Improvement Scheme }\end{array}$ & $\begin{array}{l}\text { Private sector, public sector, road } \\
\text { users, job creation and skills } \\
\text { development, improvement of } \\
\text { accessibility, traffic safety, saving on } \\
\text { traveling time due to decrease in } \\
\text { traffic congestion }\end{array}$ \\
\hline R25 billion ( $€ 2.0$ billion) & $\begin{array}{l}\text { Gautrain Rail Link } \\
\text { Project }\end{array}$ & $\begin{array}{l}\text { Private sector, public sector, public } \\
\text { transport passengers, improvement of } \\
\text { modal choice, job creation, reduction } \\
\text { in traveling time, improved traffic } \\
\text { safety, tourism promotion }\end{array}$ \\
\hline R18 billion ( $€ 1.44$ billion) & $\begin{array}{l}\text { Improvement of the } \\
\text { passenger rail system } \\
\text { over the next } 4 \text { years }\end{array}$ & $\begin{array}{l}\text { Private sector, public sector, public } \\
\text { transport passengers, job creation, less } \\
\text { traveling time, job creation, improved } \\
\text { modal choice, tourism promotion }\end{array}$ \\
\hline R13.6 billion (€1.09) & $\begin{array}{l}\text { Improvement of public } \\
\text { transport infrastructure } \\
\text { for } 2010\end{array}$ & $\begin{array}{l}\text { Private sector, public sector, public } \\
\text { transport passengers, job creation, less } \\
\text { traveling time, job creation, improved } \\
\text { modal choice, tourism promotion }\end{array}$ \\
\hline $\begin{array}{l}\text { Total: R690.30 billion } \\
\text { (€55.23 billion) }\end{array}$ & & \\
\hline
\end{tabular}

Source: Own construction from NDOT, 2008. 


\section{Alignment and integration considerations}

Transport planning, infrastructure development and provision of services do not take place in utopian space. Too often the use of the terminology of 'sustainable' is being used in a general sense. All transport planners agree with the principles supporting sustainable development. However, the environment within which transport, spatial planning and development operates is much more complex as it involves socio-economic and political realities directed by a trans-disciplinary team of experts and professionals (refer to NATMAP 2050). In promoting sustainable transport planning the content of Table 1, Figures 1 and 2 should be noted. The biggest challenge after democratization is to integrate a historically fragmented spatial system through transportation development.

Figure 3 shows the NSDP (2006) principles in analyzing the fragmented national spatial system [12]. Figure 4 shows the perspective on integration.

The contents of Figures 2, 3 and 4 - Figure 3 should be interpreted with the policy and legislative frameworks as included in Table 1 above. From the content the complicated nature to direct and focus transport planning and development can be deduced. This problematic situation is however dealt within NATMAP (2050). This statement is supported in the following announcement: 'A Transport Planning and Implementation Bill is being developed, making provision for "most of the new institutions" proposed in the national transport management plan (NATMAP) for 2050 and for making NATMAP 2050 a "statutory planning instrument"' [25].

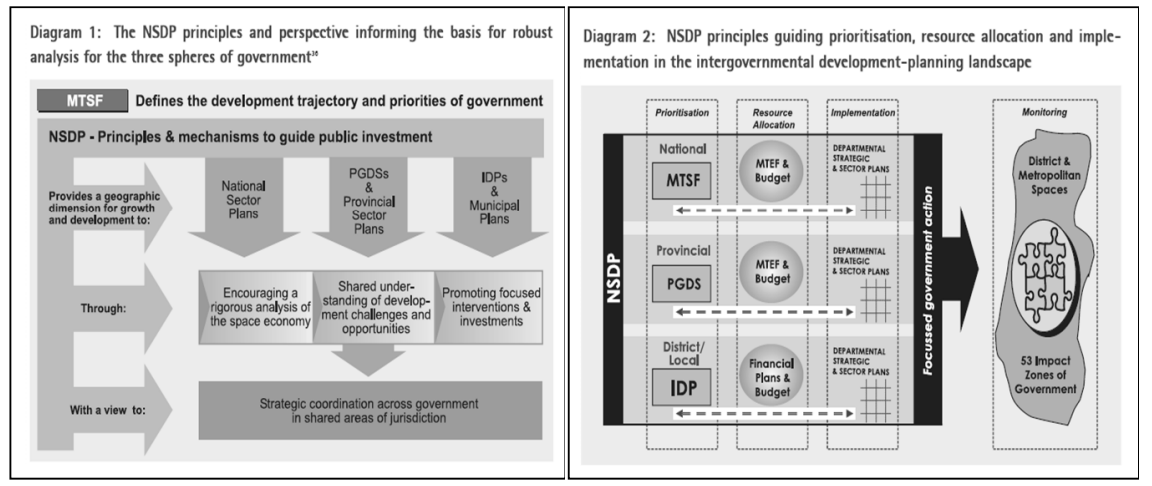

Figure 3: NSDP approach in Figure 4: NSDP perspective on analysis. integration.

\section{Conclusions}

From the abovementioned research and based on the problem statement the following conclusions can be drawn: 
- South Africa has made huge progress over the past 18 years in the transformation of its transportation policies and legislative frameworks.

- This transformation process culminated in the completion of NATMAP (2050) project.

- This process is supported by other core planning documents such as the NSDP (2006); National Growth Plan (2009); NPC Diagnostic Report (2011) and the National Development Plan (2030).

- Integration and alignment on national level to implement, ongoing assessment and managing growth and development is required in the final phase of transportation and development and transformation.

\section{References}

[1] Annual South African Transport Conference 2002: Situma, L: Challenges of transport and spatial development in the Eastern Cape. Proceedings of the 21st ASATC. University of Pretoria. (2002)

[2] Government, Department of Transport: Urban Transport Act (Act 78 of 1977). Government Printer. Pretoria. (1977)

[3] Department of Transport: National Land Transport Transition Act (Act 22 of 2000). Government Printer. Pretoria. (2000)

[4] Government: National Land Transport Act (Act 5 of 2009). Pretoria. Government Printer. (2009)

[5] Republic of South Africa: R. 1208 National Land Transport Act (5/2009): National Land Transport Regulations. Pretoria. Government Printer. (2009) and R. 877 National Land Transport Act (5/2009): National Land Transport Regulations on Contracting for Public Transport Services. Pretoria. Government Printer. (2009).

[6] Department of Transport: White Paper on National Transport Policy. Government Printer. Pretoria. (1996).

[7] Department of Transport: Moving South Africa-The Action Agenda. Departmental publication. Pretoria. (1999).

[8] Department of Transport: Rural Transport Strategy for South Africa. Departmental publication. Pretoria. (2003).

[9] Department of Transport: National Transport Master Plan (NATMAP 2050). Departmental publication on website: www.transport.gov.za. Pretoria. (2011).

[10] Office of the Presidency: National Planning Commission Diagnostic Report. Departmental publication on website: www.thepresidency.gov.za. (2011).

[11] Office of the Presidency: National Planning Commission: National Development Plan. Departmental publication on website: www.thepresidency.gov.za. (2011).

[12] Office of the Presidency: National Spatial Development Perspective. Published by The Presidency. RSA. (2006).

[13] Department of Human Settlements: Human Settlements Atlas. Compiled by the CSIR. Pretoria. (2009) 
[14] Department of Transport: National Land Transport Transition Act (Act 22 of 2000). Integrated Transport Plans: Minimum requirements for the preparation of integrated transport plans. Government Gazette 30506, Notices R.1119 and R.1120. Government Printer. Pretoria. (2007).

[15] Annual South African Transport Conference: Krynauw, M.N. and Cameron, J.W.M. National land transport key performance indicators (KPIs) as a measurement of sustainable transport: are we measuring the right things? Proceedings of the 22nd ASATC. University of Pretoria. Pretoria. (2003)

[16] Department of Transport: National Land Transport Strategic Framework (2006-2011) (Draft). Departmental publication. Pretoria. (2002)

[17] Annual South African Transport Conference: Grey, N. and Ncunyana, N. The role of municipalities in transport service delivery: a case of Amothole District Municipality. Proceedings of the 27th ASATC. University of Pretoria. Pretoria. (2008)

[18] Annual South African Transport Conference: Stapelberg, H. The role of transport planning in the quest for sustainable land use. Proceedings of the 25th ASATC. University of Pretoria. Pretoria. (2006)

[19] Department of Transport: National Transport Master Plan (NATMAP 2050). NATMAP 2050: Executive Summary December, 2010 (Draft): Departmental publication on website: www.transport.gov.za. Pretoria. (2011).

[20] GAUTRANS: Gauteng Provincial Land Transport Framework. Departmental publication. Johannesburg. (2002)

[21] Annual South African Transport Conference: Van den Berg, J.S., Krynauw, M.N, and Cameron, J.W.M. Transport performance indicators: benchmarking Tshwane against World Cities. Proceedings of the 24th ASATC. University of Pretoria. Pretoria. (2005)

[22] STATSA: Millenium Development Goals. Departmental Publication. Pretoria. (2006) and (2010).

[23] Government of South Africa: Background document: A Catalyst for Accelerated and Shared Growth in South Africa. Media briefing by the Deputy President Phumzile Mlambo-Ngcuka, 6 February, 2006. Pretoria. (2006)

[24] Office of the Presidency: National Growth Plan. Departmental declaration. Pretoria. (2009)

[25] Sabinetlaw: Announcement: Transportation planning and implementation Bill being developed. Website: http://sabinetlaw.co.za/transport/articles. (2011) 